\title{
The concentration and health risk of potentially toxic elements in black and green tea-both bagged
}

\section{and loose-leaf}

\author{
Ali Heshmati ${ }^{1}$, Freshteh Mehri ${ }^{1, "}$ Javad Karami-Momtaz ${ }^{1}$, Amin Mousavi Khaneghah ${ }^{2, "}$ \\ ${ }^{1}$ Nutrition Health Research Center, Hamadan University of Medical Sciences, Hamadan, Iran; ${ }^{2}$ Department of Food \\ Science, Faculty of Food Engineering, University of Campinas (UNICAMP), São Paulo, Brazil
}

"Corresponding Authors: Freshteh Mehri, Nutrition Health Research Center, Hamadan University of Medical Sciences, Hamadan, Iran. Email: freshteh_mehri@yahoo.com; Amin Mousavi Khaneghah, Department of Food Science, Faculty of Food Engineering, University of Campinas (UNICAMP), Rua Monteiro Lobato, 80. Caixa Postal: 6121.CEP: 13083-862, Campinas, São Paulo, Brazil. Email: mousavi@unicamp.br

Received: 28 May 2020; Accepted: 08 September 2020; Published: 23 September 2020 (c) 2020 Codon Publications

\section{OPEN ACCESS CC)(요 ORIGINAL ARTICLE}

\begin{abstract}
The concentration of potentially toxic elements (PTEs), including lead (Pb), cadmium (Cd), arsenic (As), zinc ( $\mathrm{Zn}$ ), and copper $(\mathrm{Cu})$, among 160 samples of black and green tea-both bagged and loose-leaf-in Iran was determined using a graphite furnace atomic absorption spectrophotometer (GF-AAS). Besides, the transfer rate of PTEs from made tea into tea infusion was investigated, and the related health risk for consumers was assessed. According to the results, the content of the PTEs is dependent on the type of tea (black or green), the place of cultivation (Iran or India), and the supplied form (both bagged and loose-leaf). The concentration of $\mathrm{Pb}, \mathrm{Cd}$, and As in green tea was significantly lower than black tea (P-value $<0.05$ ). On the other hand, the contents of $\mathrm{Zn}$ and $\mathrm{Cu}$ in green tea were higher than the corresponding values for black tea. The mean concentration of $\mathrm{Pb}$, As, and $\mathrm{Zn}$ in bagged tea samples was significantly higher than those of loose-leaf tea, while the $\mathrm{Cd}$ and As levels in Iranian tea samples were significantly lower than the Indian samples. Generally speaking, the mean concentration of $\mathrm{Pb}, \mathrm{Cd}, \mathrm{As}, \mathrm{Zn}$, and $\mathrm{Cu}$ were $0.59 \pm 0.12,0.12 \pm 0.06,0.16 \pm 0.12,14.23 \pm 4.90$, and $11.10 \pm 2.49 \mathrm{mg} \mathrm{kg}^{-1}$, respectively. The mean transfer rates of $\mathrm{Pb}, \mathrm{Cd}, \mathrm{As}, \mathrm{Zn}$, and $\mathrm{Cu}$ were $7.78,6.29,9.27,12.91$, and $13.08 \%$, respectively. The estimated daily intake (EDI) and noncarcinogenic quotient (target hazard quotient [THQ]) due to the ingestion of PTEs besides the carcinogenic risk of As and Cd were considered as acceptable.
\end{abstract}

Keywords: PTEs; Iran; green tea; risk assessment; black tea

\section{Introduction}

Tea prepared from Camellia sinensis leaves is the most popular nonalcoholic beverage among the global population (Atasoy et al., 2019). Tea is cultured in many countries, and China and India are the leading producers of tea (Karak and Bhagat, 2010). Moreover, the black and green tea variants are the most consumed (Pourramezani et al., 2019; Sun et al., 2019). It is assumed that 18-20 million cups of tea are consumed globally each day
(Chang, 2015). The annual per capita consumption of tea in Iran is $1.3 \mathrm{~kg}$ (3.56 $\mathrm{g} \mathrm{day}^{-1}$ ) (Falahi and Hedaiati, 2013). Tea consumption is noticeably increasing due to the reported positive effects on human health, including the reduction in blood cholesterol, improvements in immune system, antiaging properties, and the prevention of several types of diseases, such as cardiovascular diseases, Alzheimer's disease, diabetes, and different types of cancers (Khan and Mukhtar, 2019; Prasanth et al., 2019; Xu et al., 2020). Tea consumption offers some antioxidant 
compounds, such as flavonols and polyphenolic compounds, with therapeutic properties (Abass et al., 2019; Amiri et al., 2018; Benjakul et al., 2018; Hussain et al., 2019; Szymczycha-Madeja et al., 2012).

Recently, the contamination of tea by some of the potentially toxic elements (PTEs), such as lead (Pb), cadmium $(\mathrm{Cd})$, and arsenic (As), has attracted global attention (Brzezicha-Cirocka et al., 2016; Falahi and Hedaiati, 2013; Hu et al., 2014; Zhang et al., 2018a). Exposure to $\mathrm{Pb}$ may affect the central nervous system, resulting in memory disorder and delay in response time (Abass et al., 2019). Chronic exposure to As may lead to cancer of the kidney and the lung, and skin lesions (Heshmati et al., 2017, 2020). Cd is a very toxic element that can accumulate in the kidney and the bone (Saini and Dhania, 2020).

The accumulation of PTEs in tea depends on some factors, including the methods used for production, processing, and storage. At the same time, the natural occurrences of PTEs in different soils and geographical areas; the type of pesticides and fertilizers utilized in tea production; and anthropogenic sources, such as mining, traffic emissions, and industrial activities, are also among the crucial factors that have a bearing on the concentrations of PTEs in the different types of tea (Gu et al., 2014; Pourramezani et al., 2019; Zhang et al., 2018a).

The concentration of PTEs in tea consumed in Iran and other countries were investigated (Falahi and Hedaiati, 2013; Karimi et al., 2008; Lisia et al., 2019; Martín-Domingo et al., 2017; Nkansah et al., 2016; Polechońska et al., 2015; Shekoohiyan et al., 2012; Shi et al., 2007; Zhang et al., 2018b). However, very little information was found about the concentration of PTEs in black and green tea-both loose-leaf and bagged. Therefore, the main aims of the current study were to measure and compare the concentrations of $\mathrm{Cd}, \mathrm{As}, \mathrm{Pb}, \mathrm{Zn}$, and $\mathrm{Cu}$ in green and black tea, supplied as loose-leaf and bagged, and to assess the potential health risks for consumers due to ingestion of PTEs via tea consumption.

\section{Material and methods}

\section{Tea samples}

A total of 160 tea samples were collected from different supermarkets located in Hamadan city, Iran, between December 2017 and March 2018. Tea samples were divided into two groups, that is, black and green. Samples of each tea were supplied in two forms, that is, bagged and loose-leaf. As for the location of cultivation, tea samples were produced in Iran or imported from India.

\section{Chemical reagents}

All chemical reagents, including PTEs, nitric acid, and other analytical grade chemicals, were purchased from Darmstadt, Germany. The plastic vessels were washed several times with tap water and were then soaked in $20 \%$ $(\mathrm{v} / \mathrm{v})$ nitric solution for the whole night. Subsequently, samples were washed with double distilled water to remove physical contamination.

\section{Infusion preparation}

Tea infusion samples were prepared according to common procedures in Iran for tea brewing; $2.00 \mathrm{~g}$ of each tea sample was added to $100 \mathrm{~mL}$ of boiling distilled water. After 10 min of brewing, the tea infusion was filtered by Whatman No. 42 filter paper to obtain a final clear solution for further processing. The concentration of PTEs in tea infusion was measured according to the described method. The transfer rate percentage $(\mathrm{T})$ of each PTE from made tea samples into the infusion tea was estimated using the following equation (1):

$$
\mathrm{T} \%=\frac{\mathrm{C}_{1} \times 0.1 \times 100}{\mathrm{C}_{2} \times 0.002} \quad \text { Equation (1) }
$$

where $\mathrm{T}$ is the transfer rate (\%); $\mathrm{C}_{1}$ and $\mathrm{C}_{2}$ present the level of the metal in the brewed tea $\left(\mu \mathrm{g} \mathrm{L}^{-1}\right)$ and made tea $\left(\mathrm{mg} \mathrm{kg}^{-1}\right)$, respectively.

\section{Sample digestion}

Before analyzing the PTEs, in order to optimize digestion conditions, oven-dried tea samples were powdered. Then $2.00 \mathrm{~g}$ of each sample was poured into a digestion vessel. Afterward, $25 \mathrm{~mL}$ of the mixture $(3: 1 \mathrm{v} / \mathrm{v})$ of $\mathrm{HNO}_{3}$ (65\%) and $\mathrm{H}_{2} \mathrm{O}_{2}$ (35\%) was added. The sample digestion was carried out with the aid of a microwave digestion system (Topex, Preekem Scientific Instruments Co., Ltd., Shanghai, China).

The digestion consists of five stages-stage 1 ( $2 \mathrm{~min}$ at $250 \mathrm{~W})$, stage $2(2 \mathrm{~min}$ at $0 \mathrm{~W})$, stage $3(2 \mathrm{~min}$ at $250 \mathrm{~W})$, stage $4(5 \mathrm{~min}$ at $400 \mathrm{~W})$, and stage $5(5 \mathrm{~min}$ at $600 \mathrm{~W})$. Thus, the extracted sample was dissolved in $10 \mathrm{~mL}$ of distilled water; after dilution, it was filtered using filters of $0.45 \mu \mathrm{m}$ pore size before analysis by an atomic absorption spectrophotometer with a graphite furnace (Thermo Scientifics' CE 3300, Waltham, MA, USA). All digestions were repeated in triplicate. The used experimental conditions for graphite furnace atomic absorption spectrophotometer (GF-AAS) were demonstrated in Table 1. The data were presented as the average of three repeated measurements. 
Table 1. The used Graphite furnace atomic absorption spectroscopy conditions.

\begin{tabular}{lccccc} 
Parameter & Pb & Cd & As & Zn & Cu \\
\hline Wavelength $(\mathrm{nm})$ & 217 & 228.8 & 193.7 & 213.9 & 324.8 \\
Slit width $(\mathrm{nm})$ & 0.5 & 0.5 & 0.2 & 0.2 & 0.5 \\
Sensitivity $\left(\mu \mathrm{g} \mathrm{ml}^{-1}\right)$ & 2.5 & 0.8 & 6 & 0.25 & 2.5 \\
Lamp current $(\mathrm{mA})$ & 10 & 8 & 12 & 6 & 5 \\
\hline
\end{tabular}

\section{Quality assurance and quality control for the data analysis}

Quality assurance and quality control (QA/QC) were ensured based on previous studies (Heshmati et al., 2017; Martín-Domingo et al., 2017), and different factors, including recovery, the limit of detection (LOD) of the method, the limit of quantification (LOQ) of the method, and linearity were measured. The amount of LOD and LOQ were estimated using equations of $3 \mathrm{~s} / \mathrm{m}$ and $10 \mathrm{~s} / \mathrm{m}$, respectively, where " $\mathrm{s}$ " expressed the standard deviation of five replicate detections of the blank sample, and $m$ defined the slope of the standard curve for the studied PTEs. The recovery was determined by spiking the tea samples with the known concentrations of $1 \mathrm{mg}$ $\mathrm{kg}^{-1}$ for $\mathrm{Pb}, 0.1 \mathrm{mg} \mathrm{kg}^{-1}$ for $\mathrm{Cd}, 0.15 \mathrm{mg} \mathrm{kg}^{-1}$ for As, $25 \mathrm{mg}$ $\mathrm{kg}^{-1}$ for $\mathrm{Zn}$, and $50 \mathrm{mg} \mathrm{kg}^{-1}$ for $\mathrm{Cu}$, with analytical standards into the pre-analyzed tea samples (Nkansah et al., 2016). The calibration curves, linearity equations, regression coefficient $\left(\mathrm{R}^{2}\right), \mathrm{LOD}, \mathrm{LOQ}$, and recovery of studied PTEs in made tea and infusion are indicated in Table 2.

The LOQ of $\mathrm{Pb}, \mathrm{Cd}, \mathrm{As}, \mathrm{Zn}$, and $\mathrm{Cu}$ were $0.930,0.510$, $0.600,5.101$, and $5.001 \mu \mathrm{g} \mathrm{kg}^{-1}$ in made tea, and 0.046 , $0.020,0.040,0.255$, and $0.075 \mu \mathrm{g} \mathrm{L}^{-1}$ in tea infusion, respectively. The average recovery was in the range of $93.21-108.91 \%$ in made tea and $93.21-113.61 \%$ in tea infusion. The RSD percentage estimated for PTEs was lower than $2 \%$. While the LOQ of PTEs was lower than the permissible values in tea, the validated method was sensitive and suitable to determine the PTEs in made tea and also the tea infusion.

\section{Health risk assessment}

\section{Calculation of noncarcinogenic risk assessment}

For noncarcinogenic health risk assessment, the estimated daily intake (EDI) $\left(\mathrm{mg} \mathrm{kg}^{-1}\right.$ bw day-1), the target hazard quotient (THQ), and the hazard index (HI) were determined according to the following equations (Heshmati et al., 2019; Nkansah et al., 2016; USEPA, 2001):

$$
\mathrm{EDI}=\frac{\mathrm{C} 1 \times \mathrm{M} \times \mathrm{T}}{\mathrm{bw}}, \quad \text { Equation }(2)
$$

where $\mathrm{C}_{1}, \mathrm{M}, \mathrm{T}$, and bw are the mean PTE concentration $\left(\mathrm{mg} \mathrm{kg}^{-1}\right)$ of made tea, the mean daily consumption of tea $\left(3.56 \mathrm{~g} \mathrm{day}^{-1}\right)$, the transfer rate (\%) of PTE from made tea to infusion, and the average body weight of an adult $(60 \mathrm{~kg})$, respectively.

$$
\mathrm{THQ}=\frac{\mathrm{EDI}}{\mathrm{RfD}} \quad \text { Equation }(3)
$$

In this equation, reference dose (RfD) is the standard RfD suggested by the US Environmental Protection Agency (USEPA) (USEPA, 2001). Rfd of Pb, Cd, As, Zn, and $\mathrm{Cu}$ were $0.0036,0.001,0.0003,0.3$, and $0.04 \mathrm{mg} \mathrm{kg}^{-1} \mathrm{day}^{-1}$,

Table 2. The calibration curves, linear regression equations, regression coefficient $\left(R^{2}\right)$, the limit of detection (LOD), the limit of

\begin{tabular}{|c|c|c|c|c|c|c|}
\hline Metal & Range of linearity ${ }^{1}$ & Regression linear equation & Regression coefficient & LOD $^{1}$ & $\mathrm{LOQ}^{1}$ & Recovery \pm RSD \\
\hline \multicolumn{7}{|c|}{ Made tea } \\
\hline $\mathrm{Pb}$ & $2.5-1000$ & $Y=0.00826 x+0.0146$ & 0.9673 & 0.310 & 0.930 & $96.84 \pm 1.34$ \\
\hline $\mathrm{Cd}$ & $2.5-1000$ & $Y=0.02021 x-0.0161$ & 0.8966 & 0.170 & 0.510 & $108.91 \pm 1.16$ \\
\hline As & $2.5-1000$ & $Y=0.00972 x-0.0056$ & 0.9947 & 0.200 & 0.600 & $93.21 \pm 1.28$ \\
\hline $\mathrm{Zn}$ & $2.5-1000$ & $Y=0.01487 x-1.3228$ & 0.9991 & 1.703 & 5.101 & $98.43 \pm 1.62$ \\
\hline $\mathrm{Cu}$ & $2.5-1000$ & $Y=0.04476 x+0.0015$ & 0.9426 & 1.501 & 5.001 & $103.06 \pm 1.92$ \\
\hline \multicolumn{7}{|c|}{ Tea infusion } \\
\hline $\mathrm{Pb}$ & $0.1-50$ & $Y=0.00733 x+0.0126$ & 0.9681 & 0.015 & 0.046 & $100.84 \pm 2.32$ \\
\hline $\mathrm{Cd}$ & $0.1-50$ & $Y=0.01043 x-0.0151$ & 0.8943 & 0.008 & 0.020 & $98.21 \pm 1.51$ \\
\hline As & $0.1-50$ & $Y=0.00512 x-0.0051$ & 0.9921 & 0.011 & 0.040 & $107.00 \pm 1.52$ \\
\hline $\mathrm{Zn}$ & $0.1-50$ & $Y=0.03467 x-1.3028$ & 0.987 & 0.085 & 0.255 & $93.21 \pm 1.31$ \\
\hline $\mathrm{Cu}$ & $0.1-50$ & $Y=0.02473 x+0.0115$ & 0.9433 & 0.025 & 0.075 & $113.61 \pm 1.22$ \\
\hline
\end{tabular}
quantification (LOQ), and recovery of studied metals in tea.

${ }^{1} \mu \mathrm{kg}^{-1}$ for made tea and $\mu \mathrm{L} \mathrm{L}^{-1}$ for tea infusion. 
respectively (Antoine et al., 2017; USEPA, 2001; Zhang et al., 2018a)

$$
H I=\sum_{l}^{j} T H Q_{i} \quad \text { Equation (4) }
$$

HI shows the sum of each of the THQs of the whole PTE analyzed in each product (Antoine et al., 2017). If THQ and $\mathrm{HI}$ were lower than 1 , the level of health hazard was considered acceptable for health human (Qin et al., 2015).

\section{Carcinogenic risk assessment}

The International Agency for Research on Cancer considered As and $\mathrm{Cd}$ as potential carcinogenic PTEs, while $\mathrm{Zn}, \mathrm{Cu}$, and $\mathrm{Pb}$ were considered to be noncarcinogenic (IARC, 2011; Zeng et al., 2015). Carcinogenic risk (CR) of As and $\mathrm{Cd}$ was computed according to the following equation (Saha and Zaman, 2013; USEPA, 2017):

$$
\mathrm{CR}=\mathrm{EDI} \times \mathrm{SF}, \quad \text { Equation }(5)
$$

where $\mathrm{CR}$ is the carcinogenic rate per lifetime, and SF is the slope factor of cancer. According to the USEPA guidelines, $\mathrm{CR}$ in the range of $10^{-6}$ to $10^{-4}$ is acceptable. $\mathrm{SF}$ for $\mathrm{Cd}$ and As was 15 and $1.5 \mathrm{mg} \mathrm{kg}^{-1}$ day $^{-1}$, respectively (Zeng et al., 2015).

\section{Statistical analyses}

In this study, the results are shown as mean \pm SD. The statistical investigation was conducted using SPSS version 21 (SPSS Inc., Chicago, IL, USA). A sample $t$-test was employed to compare the mean concentrations of PTEs in different tea samples with the allowable limits of the Iranian National Standardization Organization (INSO, 2014a). The difference among the mean heavy metals of various samples was determined by one-way ANOVA, and the post-doc test was done using the Duncan's new multiple range test. Statistically, a P-value of $<0.05$ was considered as statistically significant.

\section{Results}

\section{The comparison between black and green tea with regard to heavy metals}

The results obtained for each of the PTEs in tea samples are shown in Tables 3 and 4 . The concentration of $\mathrm{Pb}, \mathrm{Cd}$, and As in green tea was significantly lower than that in black tea (P-value $<0.05)$. On the other hand, the concentrations of $\mathrm{Zn}$ and $\mathrm{Cu}$ in green tea were higher than that in black tea, although the difference was not significant (P-value $<0.05)$.

\section{The comparison of metals between bagged and loose-leaf tea}

The results indicated that the concentration of PTEs differed among tea samples supplied in the form of a tea bag or loose leaf, while the mean concentrations of $\mathrm{Pb}$, As, and $\mathrm{Zn}$ in bagged tea samples were significantly higher than that in loose-leaf tea (Table 3).

\section{The comparison of PTEs between Indian and Iranian tea}

The levels of $\mathrm{Cd}\left(0.10 \pm 0.07 \mathrm{mg} \mathrm{kg}^{-1}\right)$ and As $(0.13 \pm 0.06$ $\mathrm{mg} \mathrm{kg}^{-1}$ ) in Iranian tea samples were significantly lower than that in Indian samples (Cd: $0.14 \pm 0.04 \mathrm{mg} \mathrm{kg}^{-1}$ and As $0.19 \pm 0.16 \mathrm{mg} \mathrm{kg}^{-1}$ ). However, no significant differences were noted in $\mathrm{Pb}, \mathrm{Zn}$, and $\mathrm{Cu}$ contents between Iranian and Indian tea (Table 3).

\section{The transfer rate of PTE based on the infusion}

In this study, the transfer rates of $\mathrm{Pb}, \mathrm{Cd}, \mathrm{As}, \mathrm{Zn}$, and $\mathrm{Cu}$ ranged from 5.82-9.32, 5-7.27, 7.98-11.00, 10.17-17.79, $7.14-19.33 \%$, respectively, while the means were 7.78 , $6.29,9.27,12.91$, and $13.08 \%$, respectively (Table 4 ). The level of $\mathrm{Pb}, \mathrm{Cd}, \mathrm{As}, \mathrm{Zn}$, or $\mathrm{Cu}$ in brewed tea samples differed, while this index is dependent on the initial level

Table 3. The PTEs level $\left(\mathrm{mg} \mathrm{kg}^{-1}\right)$ among analyzed tea samples.

\begin{tabular}{llccccc} 
Variable & & $\mathrm{Pb}$ & $\mathrm{Cd}$ & $\mathrm{As}$ & $\mathrm{Zn}$ & $\mathrm{Cu}$ \\
\hline \multirow{2}{*}{ Tea type } & Green & $0.54 \pm 0.12$ & $0.07 \pm 0.04$ & $0.10 \pm 0.05$ & $14.66 \pm 5.74$ & $11.96 \pm 2.79$ \\
& Black & $0.65 \pm 0.10$ & $0.17 \pm 0.01$ & $0.22 \pm 0.15$ & $13.80 \pm 4.76$ & $10.25 \pm 2.18$ \\
& P-value & 0.033 & 0.015 & 0.038 & 0.084 & 0.068 \\
Tea production origin & Iran & $0.59 \pm 0.09$ & $0.10 \pm 0.07$ & $0.13 \pm 0.06$ & $14.84 \pm 6.92$ & $12.74 \pm 1.40$ \\
& India & $0.61 \pm 0.17$ & $0.14 \pm 0.04$ & $0.19 \pm 0.16$ & $13.62 \pm 2.68$ & $9.46 \pm 2.31$ \\
& P-value & 0.092 & 0.043 & 0.023 & 0.081 & 0.07 \\
Consumed form & Loose leaf & $0.69 \pm 0.08$ & $0.12 \pm 0.06$ & $0.22 \pm 0.14$ & $16.08 \pm 5.51$ & $10.17 \pm 2.79$ \\
& Bagged & $0.50 \pm 0.07$ & $0.12 \pm 0.04$ & $0.10 \pm 0.07$ & $12.39 \pm 4.08$ & $12.04 \pm 2.09$ \\
& P-value & 0.013 & 1.15 & 0.043 & 0.012 & 0.064 \\
\hline
\end{tabular}


Table 4. Level of PTEs in made tea and tea infusion.

\begin{tabular}{|c|c|c|c|c|c|c|c|c|}
\hline $\begin{array}{l}\text { Heavy metal } \\
\text { type }\end{array}$ & Tea type & $\begin{array}{l}\text { Culture } \\
\text { place }\end{array}$ & Form & $\begin{array}{c}\text { Mean } \pm S D \\
\left(\mathrm{mg} \mathrm{kg}^{-1}\right) \text { in } \\
\text { made tea }\end{array}$ & $\begin{array}{l}\text { Range } \\
\left(\mathrm{mg} \mathrm{kg}^{-1}\right) \\
\text { in made }\end{array}$ & $\begin{array}{l}\text { No. upper of } \\
\text { Iranian } \\
\text { standard (\%) }\end{array}$ & $\begin{array}{c}\text { Mean } \pm S D \\
\left(\mu g L^{-1}\right) \text { in tea } \\
\text { infusion }\end{array}$ & $\begin{array}{l}\text { Transfer } \\
\text { rate }(\%)\end{array}$ \\
\hline \multirow[t]{9}{*}{$\mathrm{Pb}$} & Black & India & Bagged & $0.79 \pm 0.4^{\mathrm{a}^{* *}}$ & $0.12-1.51$ & $3(15)$ & $2.5 \pm 0.21^{\mathrm{a}}$ & $5.82 \pm 0.12$ \\
\hline & & & Loose leaf & $0.53 \pm 0.4^{b}$ & $0.02-1.21$ & $3(15)$ & $0.82 \pm 0.01^{\mathrm{ab}}$ & $7.74 \pm 1.21$ \\
\hline & & Iran & Bagged & $0.69 \pm 0.2^{\mathrm{a}}$ & $0.42-1.32$ & $2(10)$ & $1.1 \pm 0.22^{\mathrm{a}}$ & $7.79 \pm 0.89$ \\
\hline & & & Loose leaf & $0.58 \pm 0.3^{b}$ & $0.04-1.08$ & $3(15)$ & $0.76 \pm 0.02^{\mathrm{ab}}$ & $8.64 \pm 1.02$ \\
\hline & Green & India & Bagged & $0.69 \pm 0.43^{a}$ & $0.22-2.00$ & $6(30)$ & $1.31 \pm 0.02^{\mathrm{a}}$ & $8.23 \pm 2.12$ \\
\hline & & & Loose leaf & $0.41 \pm 0.34^{c}$ & $0.03-1.20$ & $3(15)$ & $0.52 \pm 0.11^{b}$ & $6.43 \pm 0.68$ \\
\hline & & Iran & Bagged & $0.59 \pm 0.27^{b}$ & $0.10-1.03$ & $3(15)$ & $1.1 \pm 0.10^{\mathrm{a}}$ & $9.32 \pm 1.45$ \\
\hline & & & Loose leaf & $0.48 \pm 0.33^{b c}$ & $0.03-1.06$ & $2(10)$ & $0.78 \pm 0.09^{\mathrm{ab}}$ & $8.13 \pm 1.35$ \\
\hline & Total & - & - & $0.59 \pm 0.12$ & $0.02-2.00$ & $24(15)$ & $1.11 \pm 0.61$ & $7.78 \pm 0.98$ \\
\hline \multirow[t]{9}{*}{$\mathrm{Cd}$} & Black & India & Bagged & $0.18 \pm 0.23^{\mathrm{a}}$ & $0.21-0.35$ & $13(65)$ & $0.21 \pm 0.01^{\mathrm{a}}$ & $5.53 \pm 0.87$ \\
\hline & & & Loose leaf & $0.16 \pm 0.09^{a}$ & $0.07-0.39$ & $10(50)$ & $0.22 \pm 0.02^{\mathrm{a}}$ & $6.88 \pm 1.05$ \\
\hline & & Iran & Bagged & $0.11 \pm 0.09^{\mathrm{a}}$ & $0.03-0.38$ & $6(30)$ & $0.35 \pm 0.03^{\mathrm{a}}$ & $5.91 \pm 0.35$ \\
\hline & & & Loose leaf & $0.04 \pm 0.01^{b}$ & $0.01-0.09$ & $0(0)$ & $0.08 \pm 00.20^{b}$ & $6.25 \pm 0.81$ \\
\hline & Green & India & Bagged & $0.17 \pm 0.11^{\mathrm{a}}$ & $0.02-0.37$ & $14(70)$ & $0.1 \pm 0.01^{b}$ & $5.00 \pm 0.28$ \\
\hline & & & Loose leaf & $0.15 \pm 0.08^{a}$ & $0.05-0.33$ & $10(50)$ & $0.22 \pm 0.5^{\mathrm{a}}$ & $6.47 \pm 1.20$ \\
\hline & & Iran & Bagged & $0.11 \pm 0.09^{a}$ & $0.02-0.35$ & $8(40)$ & $0.21 \pm 0.01^{\mathrm{a}}$ & $7.00 \pm 1.03$ \\
\hline & & & Loose leaf & $0.03 \pm 0.03^{b}$ & $0.01-0.09$ & - & $0.16 \pm 0.09^{\mathrm{ab}}$ & $7.27 \pm 0.84$ \\
\hline & Total & & - & $0.12 \pm 0.06$ & $0.01-0.39$ & $61(76.25)$ & $0.19 \pm 0.08$ & $6.29 \pm 0.45$ \\
\hline \multirow[t]{9}{*}{ As } & Black & India & Bagged & $0.42 \pm 0.5^{\mathrm{a}}$ & $0.10-1.83$ & $10(50)$ & $0.67 \pm 0.01^{a}$ & $7.98 \pm 0.59$ \\
\hline & & & Loose leaf & $0.20 \pm 0.3^{b}$ & $0.07-1.21$ & $3(15)$ & $0.36 \pm 0.03^{a b}$ & $9.00 \pm 1.56$ \\
\hline & & Iran & Bagged & $0.20 \pm 0.3^{b}$ & $0.05-1.32$ & $2(10)$ & $0.44 \pm 0.01^{a}$ & $11.00 \pm 1.32$ \\
\hline & & & Loose leaf & $0.07 \pm 0.04^{c}$ & $0.11-0.16$ & $2(10)$ & $0.14 \pm 0.01^{b}$ & $9.50 \pm 1.65$ \\
\hline & Green & India & Bagged & $0.10 \pm 0.02^{\mathrm{bc}}$ & $0.04-0.17$ & $4(20)$ & $0.21 \pm 0.02^{\mathrm{ab}}$ & $10.00 \pm 1.85$ \\
\hline & & & Loose leaf & $0.05 \pm 0.01^{c}$ & $0.03-0.09$ & - & $0.09 \pm 0.01^{c}$ & $9.00 \pm 0.96$ \\
\hline & & Iran & Bagged & $0.17 \pm 0.21^{\mathrm{bc}}$ & $0.03-1.09$ & $3(15)$ & $0.28 \pm 0.07^{\mathrm{ab}}$ & $8.24 \pm 0.58$ \\
\hline & & & Loose leaf & $0.09 \pm 0.02^{c}$ & $0.06-0.13$ & - & $0.17 \pm 0.01^{b}$ & $9.44 \pm 0.23$ \\
\hline & Total & & - & $0.16 \pm 0.12$ & $0.03-1.83$ & $24(0.3)$ & $0.3 \pm 0.19$ & $9.27 \pm 1.09$ \\
\hline \multirow[t]{9}{*}{$\mathrm{Zn}$} & Black & India & Bagged & $11.52 \pm 1.90^{b c}$ & $8.34-15.00$ & - & $23.44 \pm 1.61^{c}$ & $10.17 \pm 2.01$ \\
\hline & & & Loose leaf & $15.16 \pm 3.03^{b}$ & $12.08-22.00$ & - & $41.35 \pm 2.61^{b}$ & $13.64 \pm 2.21$ \\
\hline & & Iran & Bagged & $8.76 \pm 3.21^{\mathrm{cd}}$ & $4.70-16.50$ & - & $22.49 \pm 3.01^{c}$ & $12.84 \pm 1.68$ \\
\hline & & & Loose leaf & $19.77 \pm 4.50^{\mathrm{a}}$ & $11.8-25.00$ & - & $48.10 \pm 0.13^{b}$ & $12.16 \pm 1.52$ \\
\hline & Green & India & Bagged & $11.20 \pm 2.70^{b c}$ & $8.30-18.80$ & - & $37 \pm 0.22^{b}$ & $16.09 \pm 2.41$ \\
\hline & & & Loose leaf & $16.60 \pm 2.93^{\mathrm{ab}}$ & $14.10-25.60$ & - & $58 \pm 0.05^{a}$ & $17.79 \pm 2.05$ \\
\hline & & Iran & Bagged & $9.02 \pm 1.24^{\mathrm{cd}}$ & $8.14-12.22$ & - & $12.2 \pm 0.14^{d}$ & $16.29 \pm 2.03$ \\
\hline & & & Loose leaf & $21.82 \pm 4.50^{\mathrm{a}}$ & $16.4-34.01$ & - & $62.2 \pm 0.01^{\mathrm{a}}$ & $14.27 \pm 2.12$ \\
\hline & Total & - & - & $14.23 \pm 4.90$ & $4.70-34.01$ & & $38.10 \pm 17.80$ & $12.91 \pm 1.59$ \\
\hline \multirow[t]{9}{*}{$\mathrm{Cu}$} & Black & India & Bagged & $7.5 \pm 3.5^{b c}$ & $2.2-13.2$ & - & $23.14 \pm 1.21 \mathrm{bc}$ & $14.43 \pm 2.01$ \\
\hline & & & Loose leaf & $9.7 \pm 1.4^{\mathrm{ab}}$ & $7.4-12.6$ & - & $30.05 \pm 0.01^{b}$ & $11.90 \pm 2.45$ \\
\hline & & Iran & Bagged & $12.6 \pm 1.2^{\mathrm{a}}$ & $9.3-16.9$ & - & $37.76 \pm 0.06^{a}$ & $12.92 \pm 2.00$ \\
\hline & & & Loose leaf & $11.2-2.5^{\mathrm{ab}}$ & $6.6-15.8$ & - & $28.33 \pm 0.4^{b}$ & $11.28 \pm 1.67$ \\
\hline & Green & India & Bagged & $8.02 \pm 4.90^{b}$ & $2.2-16.00$ & - & $29.12 \pm 3.41^{b}$ & $19.33 \pm 2.13$ \\
\hline & & & Loose leaf & $12.63 \pm 3.15^{\mathrm{a}}$ & $8.21-19.50$ & - & $25.18 \pm 2.13^{b c}$ & $12.83 \pm 2.63$ \\
\hline & & Iran & Bagged & $12.56 \pm 4.38^{\mathrm{a}}$ & $6.6-19.80$ & - & $33 \pm 3.31^{\mathrm{ab}}$ & $14.73 \pm 2.08$ \\
\hline & & & Loose leaf & $14.61 \pm 2.55^{\mathrm{a}}$ & $10.05-19.20$ & - & $18 \pm 1.15^{c}$ & $7.14 \pm 0.65$ \\
\hline & Total & - & - & $11.10 \pm 2.49$ & $2.2-19.80$ & - & $28.07 \pm 6.06$ & $13.08 \pm 1.11$ \\
\hline
\end{tabular}

The maximum level of $\mathrm{Pb}, \mathrm{Cd}, \mathrm{As}$, and $\mathrm{Cu}$ (in black tea), and $\mathrm{Cu}$ (in green tea) according to Iran standard was 1, 0.1, 0.15, 50 , and $150 \mathrm{mg} \mathrm{kg}^{-1}$, respectively. "Different letters indicated a significant difference among average values within each column $(P<0.05)$. 
of PTEs in making tea. However, there is significant difference between each PTE transfer rate from various tea samples into the infusion.

\section{The risk assessment of PTE intake through tea infusion}

The health risk based on PTE intake ( $\mathrm{Pb}, \mathrm{Cd}, \mathrm{As})$ through tea infusion consumption among the Iranian people is shown in Table 5. The results indicated that the EDI of Pb, $\mathrm{Cd}$, and As was lower than the EDI specified by the Joint FAO/WHO Expert Committee on Food Additives (JECFA) (JECFA 1993). Besides, THQ and HI amounts calculated for the above-mentioned toxic metals were lower than 1 , indicating that the levels of PTEs mentioned in tea samples are acceptable. According to Table 6, the $\mathrm{CR}$ of $\mathrm{Cd}$ and $\mathrm{As}$ was lower than the standard limit $\left(10^{-6}-10^{-4}\right)$, indicating that $\mathrm{Cd}$ and As toxicity through the consumption of green and black tea samples pose no problem and could be considered as safe for the consumer (JECFA 1993).

\section{Discussion and Conclusions}

In this study, the concentration of PTEs in tea samples consumed in western Iran was determined. The type of tea (black or green), the place of cultivation (Iran or India), and the supplied form (loose-leaf or bagged) were among the factors that were investigated.

The mean concentrations of $\mathrm{Pb}\left(0.59 \pm 0.12 \mathrm{mg} \mathrm{kg}^{-1}\right)$ and $\mathrm{Cu}\left(11.10 \pm 2.49 \mathrm{mg} \mathrm{kg}^{-1}\right)$ (Table 4) were lower than the maximum allowable limit according to Iranian standards (Pb: $1 \mathrm{mg} \mathrm{kg}^{-1}, \mathrm{Cu}: 50$ and $150 \mathrm{mg} \mathrm{kg}^{-1}$ in black and green tea, respectively). The mean concentrations of $\mathrm{Cd}(0.12$ $\left.\pm 0.06 \mathrm{mg} \mathrm{kg}^{-1}\right)$ and As $\left(0.16 \pm 0.12 \mathrm{mg} \mathrm{kg}^{-1}\right)$ were higher than the acceptable values $\left(0.1 \mathrm{mg} \mathrm{kg}^{-1}\right.$ for $\mathrm{Cd}$ and 0.15 $\mathrm{mg} \mathrm{kg}{ }^{-1}$ for As), while no significant difference was noted (P-value $>0.05$ ).

Some studies have reported lower levels of PTEs in green tea than black tea; our findings were in line with these studies (Barone et al., 2016; Podwika et al., 2018). The level of $\mathrm{Pb}$ in green tea samples $\left(0.47 \pm 0.07 \mathrm{mg} \mathrm{kg}^{-1}\right)$ analyzed by Barone et al. (2016) was lower than that of black tea $\left(0.55 \pm 0.35 \mathrm{mg} \mathrm{kg}^{-1}\right)$, although de Oliveira et al. (2018) reported higher $\mathrm{Pb}$ level in green tea $(0.76 \pm$ $\left.0.12 \mathrm{mg} \mathrm{kg}^{-1}\right)$ while compared with black tea $(0.64 \pm 0.11$ $\mathrm{mg} \mathrm{kg}^{-1}$ ) (Barone et al., 2016; de Oliveira et al., 2018). Besides, Zhong et al. (2018) reported that the $\mathrm{Pb}$ value of green tea samples from China $\left(0.48-10.57 \mathrm{mg} \mathrm{kg}^{-1}\right)$ was greater than that of black tea $\left(1.88-5.63 \mathrm{mg} \mathrm{kg}^{-1}\right)$ (Zhang et al., 2018b). It seemed that the transfer of PTEs through the industrial equipment used for black tea manufacturing, dust particles during processing, and also soldering being used in the packaging step could be accounted among the reasons for the higher level of PTEs while compared with green tea (Jin et al., 2008).

Our findings were in agreement with a study conducted by Dambiec et al. (2013), which reported that the Pb level of the bagged tea samples was significantly higher than that of loose-leaf tea (Dambiec et al., 2013). The discrepancy between PTE content of bagged and loose-leaf tea was related to the production processes and tea quality that were different for bagged and loose-leaf tea. The bagged tea generally had lower quality, compared with loose-leaf tea (Polechońska et al., 2015).

No significant difference was noted between PTE transfer rates in various kinds of tea, while Dambiec et al. (2013) found that the transfer rate of PTEs in bagged tea was higher than the corresponding values associated with loose-leaf tea. These authors believed that the orthodox process was utilized in leaf tea, causing less cellular damage than the CTC (crush, tear, and curl) process frequently utilized for bagged tea. Therefore, the leaves in bagged tea are crushed into tiny pieces, leading to a higher transfer rate of PTEs (Dambiec et al., 2013). The transfer rates of PTEs into infusion depended on the organic or inorganic form, the solubility of each PTE and their binding into tea leaves, brewing time, and temperature (Lin et al., 2006).

The average level of $\mathrm{Pb}$ in samples analyzed in our study (black tea: $0.65 \pm 0.10 \mathrm{mg} \mathrm{kg}^{-1}$; green tea: $0.54 \pm 0.12 \mathrm{mg} \mathrm{kg}^{-1}$ )

Table 5. The estimated daily intake (EDI), the total hazard quotient (THQ), and hazard index (HI) for heavy metal intake through tea consumption.

\begin{tabular}{|c|c|c|c|c|}
\hline \multirow[t]{2}{*}{ Heavy metal } & \multicolumn{2}{|c|}{ Black tea } & \multicolumn{2}{|c|}{ Green tea } \\
\hline & EDI (mg kg ${ }^{-1}$ bw day $\left.{ }^{-1}\right)$ & THQ & EDI (mg kg ${ }^{-1}$ bw day $\left.{ }^{-1}\right)$ & THQ \\
\hline $\mathrm{Pb}$ & $3.00 \mathrm{E}-06$ & 8.33E-04 & 2.49E-06 & $6.92 \mathrm{E}-04$ \\
\hline $\mathrm{Cd}$ & $6.34 \mathrm{E}-07$ & $6.34 \mathrm{E}-04$ & 2.61E-07 & $2.61 \mathrm{E}-04$ \\
\hline As & $1.21 \mathrm{E}-06$ & 4.03E-03 & $5.50 \mathrm{E}-07$ & $1.83 \mathrm{E}-03$ \\
\hline $\mathrm{Zn}$ & 1.06E-04 & $3.52 \mathrm{E}-04$ & $1.12 \mathrm{E}-04$ & $3.74 \mathrm{E}-04$ \\
\hline \multirow[t]{2}{*}{$\mathrm{Cu}$} & $7.95 \mathrm{E}-05$ & 1.99E-03 & $9.28 \mathrm{E}-05$ & $2.32 \mathrm{E}-03$ \\
\hline & \multicolumn{2}{|c|}{$\mathrm{HI}=7.84 \mathrm{E}-03$} & \multicolumn{2}{|c|}{$\mathrm{HI}=5.48 \mathrm{E}-03$} \\
\hline
\end{tabular}


Table 6. Carcinogenic rate (CR) of As and Cd intake through tea consumption.

\begin{tabular}{lccccc}
\multirow{2}{*}{$\begin{array}{l}\text { Heavy } \\
\text { metal type }\end{array}$} & \multicolumn{2}{c}{ Black tea } & & \multicolumn{2}{c}{ Green tea } \\
\cline { 2 - 3 } Cd & EDI & CR & & EDI & CR \\
\hline As & $6.34 E-07$ & $4.23 E-08$ & & $2.61 E-07$ & $1.74 E-08$ \\
\hline
\end{tabular}

The means of $\mathrm{Cd}$ and As were $0.07 \pm 0.0$ and $0.10 \pm 0.05 \mathrm{mg} \mathrm{kg}^{-1}$ in green tea, and $0.17 \pm 0.01$ and $0.22 \pm 0.15 \mathrm{mg} \mathrm{kg}^{-1}$ in black tea samples, respectively.

was higher than that reported in Italy (black tea: $0.55 \pm 0.35$ mg kg-1; green tea: $0.47 \pm 0.07 \mathrm{mg} \mathrm{kg}^{-1}$ ) (Barone et al., 2016) and lower than that reported in Slovakia (black tea: $1.387 \pm$ $0.54 \mathrm{mg} \mathrm{kg}^{-1}$; green tea: $0.875 \pm 0.59 \mathrm{mg} \mathrm{kg}^{-1}$ ), China (green tea: $3.04 \mathrm{mg} \mathrm{kg}^{-1}$ ), Saudi Arabia (black tea: $1.7 \pm 0.8 \mathrm{mg}$ $\mathrm{kg}^{-1}$ ), Turkey (black tea: $8.3 \pm 0.1 \mathrm{mg} \mathrm{kg}^{-1}$ ), Japan (black tea: $0.71 \pm 0.02 \mathrm{mg} \mathrm{kg}^{-1}$ ), China (black tea: $3.30 \pm 1.42 \mathrm{mg} \mathrm{kg}^{-1}$ ), and Iran (black tea:1.41 $\pm 0.72 \mathrm{mg} \mathrm{kg}^{-1}$ ) (Árvay et al., 2015; Fernández-Cáceres et al., 2001; Han and Li, 2002; Matsuura et al., 2001; Narin et al., 2004; Salahinejad and Aflaki, 2010). The transfer rate of $\mathrm{Pb}$ in this research (7.78\%) was lower, compared with those explained by de Oliveira et al. (2018) (33\% in green tea and $32.5 \%$ in black tea). The concentrations of $\mathrm{Pb}$ among the tea infusion samples ranged from 0.52 to $2.5 \mu \mathrm{g} \mathrm{L}{ }^{-1}$, with a mean of $1.11 \pm 0.61 \mu \mathrm{g} \mathrm{L}^{-1}$, which were lower in comparison with the limit $\left(10 \mu \mathrm{g} \mathrm{L}^{-1}\right)$ set by the World Health Organization for drinking water (WHO, 2011). The diversity observed in the $\mathrm{Pb}$ level in different studies may be related to various contaminant sources of $\mathrm{Pb}$ in tea crops, including deposits from the unclean air onto the leaves of the tea plants, the plant growth in different soils, and the geographical location (Han and Li, 2002). Cd's range and mean concentration in all tea samples were reported as $0.01-0.0 .39$ and $0.12 \pm 0.06 \mathrm{mg} \mathrm{kg}^{-1}$, respectively. Cd level in 61 (76.25\%) samples was higher than the Iranian limit $\left(0.1 \mathrm{mg} \mathrm{kg}^{-1}\right)$ (INSO, 2014a, 2014b). The highest $\left(0.18 \pm 0.23 \mathrm{mg} \mathrm{kg}^{-1}\right)$ and the lowest $\left(0.03 \pm 0.03 \mathrm{mg} \mathrm{kg}^{-1}\right)$ mean $\mathrm{Cd}$ values were found in Indian bagged black tea and Iranian loose-leaf green tea, respectively. In comparison with other studies, the average concentration of $\mathrm{Cd}$ in our study $\left(0.12 \pm 0.061 \mathrm{mg} \mathrm{kg}^{-1}\right)$ was higher than that reported by Han et al. (2005) in Japan $\left(0.1 \mathrm{mg} \mathrm{kg}^{-1}\right)$, Hosseni et al. (2013) in Iran (0.027 mg kg-1), Li et al. (2015) in China (0.05 mg kg-1) (Han et al., 2005; Hosseni et al., 2013; Li et al., 2015) and was lower than that reported by Yousefi et al. (2017) in Iran (0.19 $\left.\mathrm{mg} \mathrm{kg}^{-1}\right)$, Moreda-Piñeiro et al. (2003) in India (2.01 $\left.\mathrm{mg} \mathrm{kg}^{-1}\right)$, Saud and Oud (2003) in Japan (1.48 $\left.\mathrm{mg} \mathrm{kg}^{-1}\right)$, Narin et al. (2004) in Turkey (2.0 mg kg-1), Ashraf and Mian (2008) in Saudi Arabia (0.49 $\left.\mathrm{mg} \mathrm{kg}^{-1} \mathrm{mg} \mathrm{kg}^{-1}\right)$, Sofuoglu and Kavcar. (2008) in Turkey $\left(0.19 \mathrm{mg} \mathrm{kg}^{-1}\right)$, and Tsushida and Takeo (1977) in Japan (0.51 $\mathrm{mg} \mathrm{kg}^{-1}$ ) (Ashraf and Mian, 2008; Moreda-Pineiro et al., 2003; Narin et al., 2004; Saud and Oud, 2003; Sofuoglu and Kavcar, 2008b; Yousefi et al., 2017). When compared with other analyzed PTEs, the transfer rate of $\mathrm{Cd}$ (6.29\%) was lower, which might be related to the strong connection between $\mathrm{Cd}$ and the tea matrix (Matsuura et al., 2001). The results indicated that the mean level of Cd $\left(0.19 \mu \mathrm{g} \mathrm{L}^{-1}\right)$ in tea infusion was similar to a previous study (Sofuoglu and Kavcar, 2008) and lower than the maximum contaminant level in drinking water, that is, $3 \mu \mathrm{g} \mathrm{L}-1$ (WHO, 2011). It should be mentioned that $\mathrm{Cd}$ is a hepatotoxic and nephrotoxic metal, and persistent exposure to it may negatively impact the proximal tubular cells related to the kidneys and lead to renal failure in humans (Byber et al., 2016; Heshmati and Salaramoli, 2015).

In the current investigation, seven (8.75\%) green tea samples and 17 (21.25\%) black tea samples had higher As content than the maximum limit $(0.15 \mathrm{mg} \mathrm{kg}-1)$ per the INSO (2014a, 2014b). While the average As in the current study $\left(0.16 \mathrm{mg} \mathrm{kg}^{-1}\right)$ was lower than that demonstrated by de Oliveira et al. (2018) in the United States (green tea: $0.18 \pm 0.07 \mathrm{mg} \mathrm{kg}^{-1} \mathrm{in}$; black tea: $\left.0.22 \pm 0.02 \mathrm{mg} \mathrm{kg}^{-1}\right)$, Shi et al. (2007) in China $\left(0.30 \mathrm{mg} \mathrm{kg} \mathrm{kg}^{-1}\right)$, Nejatolahi et al. (2014) in Iran (0. $\left.\mathrm{mg} \mathrm{kg}^{-1}\right)$, Martín-Domingo et al. (2017) in Spain (0.20 mg kg-1), and Sofuoglu et al. (2008) in Turkey $\left(0.21 \mathrm{mg} \mathrm{kg}^{-1}\right)$, it was higher than the corresponding values reported by Milani et al. (2016) in Brazil (0.021 $\left.\mathrm{mg} \mathrm{kg}^{-1}\right)$, Nookabkaew et al. (2006) in China (0.01 mg kg-1), Karimi et al. (2008) in Iran (0.11 mg kg-1), Zhelev et al. (2019) in India (0.05 $\left.\mathrm{mg} \mathrm{kg}^{-1}\right)$, and Popović et al. (2017) in Belgrade (0.04 $\mathrm{mg} \mathrm{kg}^{-1}$ ) (de Oliveira et al., 2018; Karimi et al., 2008; Martín-Domingo et al., 2017; Milani et al., 2016; Nejatolahi et al., 2014; Nookabkaew et al., 2006; Popović et al., 2017; Shi et al., 2007; Sofuoglu and Kavcar, 2008b; Zhelev et al., 2019). As concentration in tea, infusion samples ranged from 0.09 to $0.67 \mu \mathrm{g} \mathrm{L}^{-1}$, while the recorded transfer rate was between 7.98 and $11.00 \%$. Arsenic levels in all tea infusions were below the MRL (10 $\left.\mathrm{g} \mathrm{L} \mathrm{L}^{-1}\right)$ in drinking water (WHO, 2011). The mean As content in the tea infusion sample in our study was higher than that analyzed by Szymczycha-Madeja et al. (2012) and Sofuoglu and Kavcar (2008), and lower than samples investigated by Schwalfenberg et al. (2013) (Schwalfenberg et al., 2013; Sofuoglu and Kavcar, 2008). The discrepancies in different studies may be related to the ratio of pollution in various regions, the type of pesticides and fertilizers utilized in tea culture, the attributes of soils, the tea cultivars, and the brewing methods (Chen et al., 2006; Karak et al., 2016; Tokalığlu and Kartal, 2004). The exposure to a high level of As via daily consumption of tea could lead to different side effects, such as skin cancers and internal diseases. There are also reports of a significant association between exposure to As and cancer of the liver, prostate, and bladder (Hong et al., 2014).

As shown in Table 4, $\mathrm{Zn}$ was the PTE identified the most in this current study. $\mathrm{Zn}$ is considered an essential 
element and has an important role in most of the metabolic activities (Abass et al., 2019; Heshmati et al., 2019). The insufficiency of $\mathrm{Zn}$ daily can lead to diminishing appetite, slowing growth, skin disorders, and immune system abnormalities (Salgueiro et al., 2000). Exposure to high amounts of $\mathrm{Zn}$ could lead to nausea, vomiting, diarrhea, and prostate cancer (Plum et al., 2010). Based on the recommended daily consumption (RDI) of $\mathrm{Zn}$ for adults $\left(15 \mathrm{mg} \mathrm{day}^{-1}\right)$, the maximum daily $\mathrm{Zn}$ intake through tea consumption was estimated at $0.1 \%$ of RDI for this element (Salgueiro et al., 2000; Zhang et al., 2018b). The average consumption of $\mathrm{Zn}(14.23 \pm 4.90$ $\mathrm{mg} \mathrm{kg}^{-1}$ ) in our study was lower than the value described by Srividhya et al. (2011) in green tea $\left(26.39 \mathrm{mg} \mathrm{kg}^{-1}\right)$ of India, Podwika et al. (2018) in green tea $\left(24.4 \mathrm{mg} \mathrm{kg}^{-1}\right)$ of Poland, Falahi and Hedaiati, (2013) in black tea (28.8 mg $\mathrm{kg}^{-1}$ ) of Iran (Falahi and Hedaiati, 2013; Podwika et al., 2018; Srividhya et al., 2011).

$\mathrm{Cu}$ is one of the PTEs found in tea, which is a major element present in various polyphenol oxidase enzymes (Zhang et al., 2018b). According to the INSO (2014a, 2014b), the permitted level for $\mathrm{Cu}$ in green and black tea are 150 and $50 \mathrm{mg} \mathrm{kg}^{-1}$, respectively. In the current study, the $\mathrm{Cu}$ level of all samples was less than the mentioned limits. $\mathrm{Cu}$ is an important element, and its presence in tea can be beneficial for human beings, although a high dose is toxic. Considering the daily consumption of made tea $(3.56 \mathrm{~g})$, the maximum $\mathrm{Cu}$ level in samples analyzed in the current study $\left(19.80 \mathrm{mg} \mathrm{kg}^{-1}\right)$, and the transfer rate of $13.08 \%$, the daily $\mathrm{Cu}$ intake through tea among Iranian consumers was estimated to be $0.0092 \mathrm{mg}$, which is $0.46 \%$ of the RDI ( $2 \mathrm{mg}$ ) for this element in adults (Goldhaber, 2003). The maximum transfer rate of $\mathrm{Cu}$ in our study (19.33\%) was less than the findings reported by Zhang et al. (2018b) in China (24\%), Brzezicha-Cirocka et al. (2016) in different geographical areas of China (27\%), Matsuura et al. (2001) in Japan (23\%), and Street et al. (2006) in tea samples (30\%) imported into China (Brzezicha-Cirocka et al., 2016; Matsuura et al., 2001; Street et al., 2006; Zhang et al., 2018b). The discrepancy between the present study data and the previous research was related to the existence of different contaminant sources of heavy metals in tea production areas, tea storage and processing procedures, and packaging (Han et al., 2006).

In the current study, EDI values of the mentioned PTEs in tea samples were reduced in the following order: $\mathrm{Zn}>$ $\mathrm{Cu}>\mathrm{Pb}>\mathrm{As}>\mathrm{Cd}$. Soliman (2016) indicated EDI levels of $\mathrm{Cu}$ and $\mathrm{Pb}$ in tea as 0.7 and 0.007 (mg day ${ }^{-1}$ ), respectively, which was higher than our findings (Soliman, 2016). In our study, the THQ level of metals in black tea and green tea was in the order of $\mathrm{Pb}>\mathrm{Cd}>\mathrm{As}>\mathrm{Zn}>\mathrm{Cu}$ and $\mathrm{Pb}>\mathrm{Zn}>\mathrm{Cd}>\mathrm{Cu}>$ As. The THQ associated with PTEs in Sri Lankan and Indian black tea were reported as $\mathrm{Cu}>\mathrm{As}>\mathrm{Pb}>\mathrm{Cd}>\mathrm{Hg}$ and $\mathrm{As}>\mathrm{Cu}>\mathrm{Pb}>\mathrm{Cd}>\mathrm{Hg}$, respectively (Pourramezani et al., 2019). In other investigations carried out by Gruszecka-Kosowska and MazurKajta (2016) and Zhang et al. (2018), similar THQ and HI values were reported (Gruszecka-Kosowska and MazurKajta, 2016; Zhang et al., 2018a).

In conclusion, in this study, the concentration of PTEs and the health risk of tea consumed in western Iran were investigated. $\mathrm{Pb}, \mathrm{Cd}, \mathrm{As}, \mathrm{Zn}$, and $\mathrm{Cu}$ content were compared between the tea variants (black or green) cultivated in two different places, that is, Iran or India, and supplied as loose-leaf or bagged tea. The mean $\mathrm{Pb}(0.59 \pm 0.12 \mathrm{mg}$ $\left.\mathrm{kg}^{-1}\right)$ and $\mathrm{Cu}\left(11.10 \pm 2.49 \mathrm{mg} \mathrm{kg}^{-1}\right)$ were lower than the maximum allowable limit according to the INSO $(\mathrm{Pb}$ : $1 \mathrm{mg} \mathrm{kg}^{-1}, \mathrm{Cu}: 50$ and $150 \mathrm{mg} \mathrm{kg}^{-1}$ in black and green tea, respectively). The mean of $\mathrm{Cd}\left(0.12 \pm 0.06 \mathrm{mg} \mathrm{kg}^{-1}\right)$ and As $\left(0.16 \pm 0.12 \mathrm{mg} \mathrm{kg}^{-1}\right)$ was higher than the acceptable value ( $0.1 \mathrm{mg} \mathrm{kg}^{-1}$ for $\mathrm{Cd}$ and $0.15 \mathrm{mg} \mathrm{kg}^{-1}$ for As), although no significant difference was noted. The statistical data showed that the level of $\mathrm{Pb}, \mathrm{Cd}$, and As in green tea was significantly lower than that of black tea (P-value $<0.05$ ). Also, the mean $\mathrm{Pb}$, As, and $\mathrm{Zn}$ in bagged tea samples was significantly higher than in loose-leaf tea. Furthermore, the $\mathrm{Cd}$ and As levels in Iranian tea samples were significantly lower than the Indian samples. The mean transfer rates of $\mathrm{Pb}, \mathrm{Cd}, \mathrm{As}, \mathrm{Zn}$, and $\mathrm{Cu}$ were 7.78, 6.29, 9.27, 12.91, and $13.08 \%$, respectively. An estimate of the non-CR of whole metals and CR for As and Cd indicated that tea consumption posed no health risk to Iranian consumers.

\section{References}

Abass, A., Awoyale, W. and Alamu, E., 2019. Assessment of the chemical and trace metal composition of dried cassava products from Nigeria. Quality Assurance and Safety of Crops \& Foods 11: 43-52. https://doi.org/10.3920/QAS2018.1273

Amiri, S., Akhavan, H., Zare, N. and Radi, M., 2018. Effect of gelatin-based edible coatings incorporated with aloe vera and green tea extracts on the shelf-life of fresh-cut apple. 9764650. Italian Journal of Food Science 30. https://doi. org/10.14674/1120-1770-IJFS699

Antoine, J.M., Fung, L.A.H. and Grant, C.N., 2017. Assessment of the potential health risks associated with the aluminium, arsenic, cadmium and lead content in selected fruits and vegetables grown in Jamaica. Toxicology Reports 4: 181-187. https://doi. org/10.1016/j.toxrep.2017.03.006

Árvay, J., Hauptvogl, M., Tomáš, J. and Harangozo, L., 2015. Determination of mercury, cadmium and lead contents in different tea and teas infusions (Camellia sinensis, L.). Potravinarstvo 9: 398-402. https://doi.org/10.5219/510

Ashraf, W. and Mian, A.A., 2008. Levels of selected heavy metals in black tea varieties consumed in Saudi Arabia. Bulletin of Environmental Contamination and Toxicology 81: 101-104. https://doi.org/10.1007/s00128-008-9402-0 
Atasoy, A.D., Yesilnacar, M.I. and Atasoy, A.F., 2019. Essential element contents of Turkish black tea, non-alcoholic beverages. Elsevier, Woodhead Publishing, pp. 63-72.

Barone, G., Giacominelli-Stuffler, R. and Storelli, M.M., 2016. Evaluation of trace metal and polychlorinated biphenyl levels in tea brands of different origin commercialized in Italy. Food and Chemical Toxicology 87: 113-119. https://doi.org/10.1016/j. fct.2015.12.008

Benjakul, S., Pisuchpen, S., O’Brien, N. and Karnjanapratum, S., 2018. Effect of antioxidants and packing conditions on storage stability of cereal bar fortified with hydrolyzed collagen from seabass skin. Italian Journal of Food Science 31: 347-366. https://doi.org/10.14674/IJFS-1211

Brzezicha-Cirocka, J., Grembecka, M. and Szefer, P., 2016. Monitoring of essential and heavy metals in green tea from different geographical origins. Environmental Monitoring and Assessment 188: 183. https://doi.org/10.1007/s10661-016$5157-\mathrm{y}$

Byber, K., Lison, D., Verougstraete, V., Dressel, H. and Hotz, P., 2016. Cadmium or cadmium compounds and chronic kidney disease in workers and the general population: a systematic review. Critical Reviews in Toxicology 46: 191-240. https://doi.org/10. 3109/104.08444.2015.1076375

Chang, K., 2015. World tea production and trade: current and future development. Food and Agriculture Organization Of The United Nations, Rome.

Chen, Z., Cai, Y., Solo-Gabriele, H., Snyder, G.H. and Cisar, J.L., 2006. Interactions of arsenic and the dissolved substances derived from turf soils. Environmental Science \& Technology 40: 4659-4665. https://doi.org/10.1021/es060619m

Dambiec, M., Polechońska, L. and Klink, A., 2013. Levels of essential and non-essential elements in black teas commercialized in Poland and their transfer to tea infusion. Journal of Food Composition and Analysis 31: 62-66. https://doi.org/10.1016/j. jfca.2013.03.006

de Oliveira, L.M., Das, S., da Silva, E.B., Gao, P., Gress, J., Liu, Y. and Ma, L.Q., 2018. Metal concentrations in traditional and herbal teas and their potential risks to human health. Science of the Total Environment 633: 649-657. https://doi.org/10.1016/j. scitotenv.2018.03.215

Falahi, E. and Hedaiati, R., 2013. Heavy metal content of black teas consumed in Iran. Food Additives \& Contaminants: Part B 6: 123-126. https://doi.org/10.1080/19393210.2013.764550

Fernández-Cáceres, P.L., Martín, M.J., Pablos, F. and González, A.G., 2001. Differentiation of tea (Camellia sinensis) varieties and their geographical origin according to their metal content. Journal of Agricultural and Food Chemistry 49: 4775-4779. https://doi. org/10.1021/jf0106143

Goldhaber, S.B., 2003. Trace element risk assessment: essentiality vs. toxicity. Regulatory Toxicology and Pharmacology 38: 232242. https://doi.org/10.1016/S0273-2300(02)00020-X

Gruszecka-Kosowska, A. and Mazur-Kajta, K., 2016. Potential health risk of selected metals for Polish consumers of oolong tea from the Fujian Province, China. Human and Ecological Risk Assessment: An International Journal 22: 1147-1165. https:// doi.org/10.1080/10807039.2016.1146572
Gu, Y.G., Li, Q.S., Fang, J.H., He, B.Y., Fu, H.B. and Tong, Z.J., 2014. Identification of heavy metal sources in the reclaimed farmland soils of the pearl river estuary in China using a multivariate geostatistical approach. Ecotoxicology and Environmental Safety 105: 7-12. https://doi.org/10.1016/j.ecoenv.2014.04.003

Han, L. and Li, R., 2002. Determination of minerals and trace elements in various tea by ICP-AES. Guang pu 22: 304-306.

Han, W.-Y., Shi, Y.-Z., Ma, L.-F. and Ruan, J.-Y., 2005. Arsenic, cadmium, chromium, cobalt, and copper in different types of Chinese tea. Bulletin of Environmental Contamination and Toxicology 75: 272-277. https://doi.org/10.1007/s00128-005-0748-2

Han, W.-Y., Zhao, F.-J., Shi, Y.-Z., Ma, L.-F. and Ruan, J.-Y., 2006. Scale and causes of lead contamination in Chinese tea. Environmental Pollution 139: 125-132. https://doi.org/10.1016/j. envpol.2005.04.025

Heshmati, A., Karami-Momtaz, J., Nili-Ahmadabadi, A. and Ghadimi, S., 2017. Dietary exposure to toxic and essential trace elements by consumption of wild and farmed carp (Cyprinus carpio) and Caspian kutum (Rutilus frisii kutum) in Iran. Chemosphere 173: 207-215. https://doi.org/10.1016/j. chemosphere.2017.01.009

Heshmati, A., Mehri, F., Karami-Momtaz, J. and Mousavi Khaneghah, A., 2020. Concentration and risk assessment of potentially toxic elements, lead and cadmium, in vegetables and cereals consumed in Western Iran. Journal of Food Protection 83: 101-107. https://doi.org/10.4315/0362-028x.jfp-19-312

Heshmati, A., Sadati, R., Ghavami, M. and Mousavi Khaneghah, A., 2019. The concentration of potentially toxic elements (PTEs) in muscle tissue of farmed Iranian rainbow trout (Oncorhynchus mykiss), feed, and water samples collected from the west of Iran: a risk assessment study. Environmental Science and Pollution Research 26: 34584-34593. https://doi.org/10.1007/s11356-019-06593-x

Heshmati, A. and Salaramoli, J., 2015. Distribution pattern of cadmium in liver and kidney of broiler chicken: an experimental study. Journal of Food Quality and Hazards Control 2: 15-19.

Hong, Y.-S., Song, K.-H. and Chung, J.-Y., 2014. Health effects of chronic arsenic exposure. Journal of Preventive Medicine and Public Health 47: 245. https://doi.org/10.3961/jpmph.14.035

Hosseni, S., Shakerian, A. and Moghimi, A., 2013. Cadmium and lead content in several brands of black tea (Camellia sinensis) in Iran. Journal of Food Biosciences and Technology 3: 67-72.

Hu, W., Chen, Y., Huang, B. and Niedermann, S., 2014. Health risk assessment of heavy metals in soils and vegetables from a typical greenhouse vegetable production system in China. Human and Ecological Risk Assessment: An International Journal 20: 12641280. https://doi.org/10.1080/10807039.2013.831267

Hussain, N., Ishak, I., Harith, N.M. and Kuan, G.L.P., 2019. Comparison of bioactive compounds and sensory evaluation on edible flowers tea infusion. Italian Journal of Food Science 31: 264-273. https:// doi.org/10.14674/IJFS-1071

IARC, 2011. Agents classified by the IARC monographs. In: Julia Smedley, Finlay Dick, and Steven Sadhra (Eds) Oxford handbook of occupational health. OUP Oxford, Oxford, UK.

INSO, 2014a. Black tea - specifications and test methods. 3rd revision. No. 623. Iranian National Standardization Organization, Karaj, Iran. 
INSO, 2014b. Green tea-specifications and test methods. 1st revision. No. 10768. Iranian National Standardization Organization, Kraj. Iran.

JECFA 1993 Joint FAO/WHO Expert Committee on Food Additives. Evaluation of certain food additives and contaminants: 41st report of the Joint FAO/WHO Expert Committee on Food Additives. World Health Organization, Geneva. Technical Reports Series No. 837.

Jin, C.W., Du, S.T., Zhang, K. and Lin, X.Y., 2008. Factors determining copper concentration in tea leaves produced at Yuyao County, China. Food and Chemical Toxicology 46: 2054-2061. https://doi.org/10.1016/j.fct.2008.01.046

Karak, T. and Bhagat, R., 2010. Trace elements in tea leaves, made tea and tea infusion: a review. Food Research International 43: 2234-2252. https://doi.org/10.1016/j.foodres.2010.08.010

Karak, T., Paul, R., Sonar, I., Nath, J., Boruah, R. and Dutta, A., 2016. Nickel dynamics influenced by municipal solid waste compost application in tea (Camellia sinensis L.): a cup that cheers. International Journal of Environmental Science and Technology 13: 663-678. https://doi.org/10.1007/s13762-015-0900-4

Karimi, G., Hasanzadeh, M., Nili, A., Khashayarmanesh, Z., Samiei, Z., Nazari, F. and Teimuri, M., 2008. Concentrations and health risk of heavy metals in tea samples marketed in Iran. Pharmacology 3: 164-174.

Khan, N. and Mukhtar, H., 2019. Tea polyphenols in promotion of human health. Nutrients 11: 39. https://doi.org/10.3390/ nu11010039

Li, L., Fu, Q.L., Achal, V. and Liu, Y., 2015. A comparison of the potential health risk of aluminum and heavy metals in tea leaves and tea infusion of commercially available green tea in Jiangxi, China. Environmental Monitoring and Assessment 187: 1-12. https://doi.org/10.1007/s10661-015-4445-2

Lin, D., Zhu, L. and Luo, L., 2006. Factors affecting transfer of polycyclic aromatic hydrocarbons from made tea to tea infusion. Journal of Agricultural and Food Chemistry 54: 4350-4354. https://doi.org/10.1021/jf060189j

Lisia, M., Priscila, D., Jaylei, M.G. and Silvana, C.J., 2019. Determination of arsenic, cadmium and lead concentration in teas, commercialized in Rio De Janeiro, Brazil, and their transfer to tea infusion. Journal of Mathematics 2015: 179-186.

Martín-Domingo, M.C., Pla, A., Hernández, A., Olmedo, P., NavasAcien, A., Lozano-Paniagua, D. and Gil, F., 2017. Determination of metalloid, metallic and mineral elements in herbal teas. Risk assessment for the consumers. Journal of Food Composition and Analysis 60: 81-89. https://doi.org/10.1016/j.jfca.2017.03.009

Matsuura, H., Hokura, A., Katsuki, F., Itoh, A. and Haraguchi, H., 2001. Multielement determination and speciation of major-totrace elements in black tea leaves by ICP-AES and ICP-MS with the aid of size exclusion chromatography. Analytical Sciences 17: 391-398. https://doi.org/10.2116/analsci.17.391

Milani, R.F., Morgano, M.A. and Cadore, S., 2016. Trace elements in Camellia sinensis marketed in southeastern Brazil: extraction from tea leaves to beverages and dietary exposure. LWT-Food Science and Technology 68: 491-498. https://doi.org/10.1016/j. lwt.2015.12.041
Moreda-Pineiro, A., Fisher, A. and Hill, S.J., 2003. The classification of tea according to region of origin using pattern recognition techniques and trace metal data. Journal of Food Composition and Analysis 16: 195-211. https://doi.org/10.1016/ S0889-1575(02)00163-1

Narin, I., Colak, H., Turkoglu, O., Soylak, M. and Dogan, M., 2004. Heavy metals in black tea samples produced in Turkey. Bulletin of Environmental Contamination and Toxicology 72: 844-849. https://doi.org/10.1007/s00128-004-0321-4

Nejatolahi, M., Mortazavi, S. and Ildoromi, A., 2014. Levels of $\mathrm{Cu}$, $\mathrm{Zn}, \mathrm{Pb}$, and $\mathrm{Cd}$ in the leaves of the tea plant (Camellia sinensis) and in the soil of Gilan and Mazandaran farms of Iran. Journal of Food Measurement and Characterization 8: 277-282. https:// doi.org/10.1007/s11694-014-9186-3

Nkansah, M.A., Opoku, F. and Ackumey, A.A., 2016. Risk assessment of mineral and heavy metal content of selected tea products from the Ghanaian market. Environmental Monitoring and Assessment 188: 332. https://doi.org/10.1007/ s10661-016-5343-y

Nookabkaew, S., Rangkadilok, N. and Satayavivad, J., 2006. Determination of trace elements in herbal tea products and their infusions consumed in Thailand. Journal of Agricultural and Food Chemistry 54: 6939-6944. https://doi.org/10.1021/ jf060571w

Plum, L.M., Rink, L. and Haase, H., 2010. The essential toxin: impact of zinc on human health. International Journal of Environmental Research and Public Health 7: 1342-1365. https://doi. org/10.3390/ijerph7041342

Podwika, W., Kleszcz, K., Krośniak, M. and Zagrodzki, P., 2018. Copper, manganese, zinc, and cadmium in tea leaves of different types and origin. Biological Trace Element Research 183: 389395. https://doi.org/10.1007/s12011-017-1140-x

Polechońska, L., Dambiec, M., Klink, A. and Rudecki, A., 2015. Concentrations and solubility of selected trace metals in leaf and bagged black teas commercialized in Poland. Journal of Food and Drug Analysis 23: 486-492. https://doi.org/10.1016/j. jfda.2014.08.003

Popović, S., Pantelić, A., Milovanović, Ž., Milinkov, J. and Vidović, M., 2017. Analysis of tea for metals by flame and graphite furnace atomic absorption spectrometry with multivariate analysis. Analytical Letters 50: 2619-2633. https://doi.org/10.1080/00032 719.2017.1307849

Pourramezani, F., Akrami Mohajeri, F., Salmani, M.H., Dehghani Tafti, A. and Khalili Sadrabad, E., 2019. Evaluation of heavy metal concentration in imported black tea in Iran and consumer risk assessments. Food Science \& Nutrition 7: 4021-4026. https://doi.org/10.1002/fsn3.1267

Prasanth, M.I., Sivamaruthi, B.S., Chaiyasut, C. and Tencomnao, T., 2019. A review of the role of green tea (Camellia sinensis) in antiphotoaging, stress resistance, neuroprotection, and autophagy. Nutrients 11: 474. https://doi.org/10.3390/nu11020474.

Qin, D., Jiang, H., Bai, S., Tang, S. and Mou, Z., 2015. Determination of 28 trace elements in three farmed cyprinid fish species from Northeast China. Food Control 50: 1-8. https://doi. org/10.1016/j.foodcont.2014.08.016 
Saha, N. and Zaman, M., 2013. Evaluation of possible health risks of heavy metals by consumption of foodstuffs available in the central market of Rajshahi City, Bangladesh. Environmental Monitoring and Assessment 185: 3867-3878. https://doi. org/10.1007/s10661-012-2835-2

Saini, S. and Dhania, G., 2020. Cadmium as an environmental pollutant: ecotoxicological effects, health hazards, and bioremediation approaches for its detoxification from contaminated sites, bioremediation of industrial waste for environmental safety. Springer, Singapore, pp. 357-387.

Salahinejad, M. and Aflaki, F., 2010. Toxic and essential mineral elements content of black tea leaves and their tea infusions consumed in Iran. Biological Trace Element Research 134: 109-117. https://doi.org/10.1007/s12011-009-8449-z

Salgueiro, M.J., Zubillaga, M., Lysionek, A., Sarabia, M.I., Caro, R., De Paoli, T., Hager, A., Weill, R. and Boccio, J., 2000. Zinc as an essential micronutrient: a review. Nutrition Research 20: 737755. https://doi.org/10.1016/S0271-5317(00)00163-9

Saud, S. and Oud, A., 2003. Heavy metal contents in tea and herb leaves. Pakistan Journal of Biological Science 6: 208-202. https://doi.org/10.3923/pjbs.2003.208.212

Schwalfenberg, G., Genuis, S.J. and Rodushkin, I., 2013. The benefits and risks of consuming brewed tea: beware of toxic element contamination. Journal of Toxicology. 370460. https://doi. org/10.1155/2013/370460

Shekoohiyan, S., Ghoochani, M., Mohagheghian, A., Mahvi, A.H., Yunesian, M. and Nazmara, S., 2012. Determination of lead, cadmium and arsenic in infusion tea cultivated in north of Iran. Iranian Journal of Environmental Health Science \& Engineering 9: 37. https://doi.org/10.1186/1735-2746-9-37

Shi, Y., Jin, L. and Zhu, Y., 2007. The contents status quo and the accumulation characteristic of heavy metal in tea. China Tea 6: $17-19$.

Sofuoglu, S.C. and Kavcar, P., 2008. An exposure and risk assessment for fluoride and trace metals in black tea. Journal of Hazardous Materials 158: 392-400. https://doi.org/10.1016/j. jhazmat.2008.01.086

Soliman, N., 2016. Metals contents in black tea and evaluation of potential human health risks to consumers. Health Economics \& Outcome Research: Open Access 2: 1-4. https://doi. org/10.4172/24.71-268X.1000109

Srividhya, B., Subramanian, R. and Raj, V., 2011. Determination of lead, manganese, copper, zinc, cadmium, nickel and chromium in tea leaves. International Journal of Pharmacy and Pharmaceutical Sciences 13: 257-258.

Street, R., Szakova, J., Drabek, O. and Mladkova, L., 2006. The status of micronutrients $(\mathrm{Cu}, \mathrm{Fe}, \mathrm{Mn}, \mathrm{Zn})$ in tea and tea infusions in selected samples imported to the Czech Republic. Czech Journal of Food Sciences 24: 62. https://doi.org/10.17221/3301-CJFS

Sun, L., Xu, H., Ye, J. and Gaikwad, N.W., 2019. Comparative effect of black, green, oolong, and white tea intake on weight gain and bile acid metabolism. Nutrition 65: 208-215. https://doi. org/10.1016/j.nut.2019.02.006

Szymczycha-Madeja, A., Welna, M. and Pohl, P., 2012. Elemental analysis of teas and their infusions by spectrometric methods.
TrAC Trends in Analytical Chemistry 35: 165-181. https://doi. org/10.1016/j.trac.2011.12.005

Tokalıoğlu, Ş. and Kartal, Ş., 2004. Bioavailability of soil-extractable metals to tea plant by BCR sequential extraction procedure. Instrumentation Science \& Technology 32: 387-400. https://doi. org/10.1081/CI-120037671

Tsushida T, Takeo T. 1977. Zinc, copper, lead and cadmium contents in green tea. Journal of the Science of Food and Agriculture 28: 255-258.

USEPA, 2001. Risk assessment guidance for superfund: volume III part A, process for conducting probabilistic risk assessment. US Environmental Protection Agency, Washington, DC.

USEPA, 2017. Integrated Risk Information System (IRIS). Available at: https://www.epa.gov/iris.

WHO, 2011. Guidelines for drinking-water quality. World Health Organization.

Xu, X.-Y., Zhao, C.-N., Cao, S.-Y., Tang, G.-Y., Gan, R.-Y. and Li, H.-B., 2020. Effects and mechanisms of tea for the prevention and management of cancers: an updated review. Critical Reviews in Food Science and Nutrition 60: 1693-1705. https:// doi.org/10.1080/10408398.2019.1588223

Yousefi, N., Jahangard, A. and Mahmoudian, M.H., 2017. Heavy metal concentration in black tea in Iran. Archives of Hygiene Sciences 6: 128-135. https://doi.org/10.29252/ ArchHygSci.6.2.128

Zeng, F., Wei, W., Li, M., Huang, R., Yang, F. and Duan, Y., 2015. Heavy metal contamination in rice-producing soils of Hunan province, China and potential health risks. International Journal of Environmental Research and Public Health 12: 15584-15593. https://doi.org/10.3390/ijerph121215005

Zhang, J., Yang, R., Chen, R., Peng, Y., Wen, X. and Gao, L., 2018a. Accumulation of heavy metals in tea leaves and potential health risk assessment: a case study from Puan county, Guizhou province, China. International Journal of Environmental Research and Public Health 15: 133. https://doi.org/10.3390/ ijerph15010133

Zhang, L., Zhang, J., Chen, L., Liu, T., Ma, G. and Liu, X., 2018b. Influence of manufacturing process on the contents of iron, copper, chromium, nickel and manganese elements in crush, tear and curl black tea, their transfer rates and health risk assessment. Food Control 89: 241-249. https://doi.org/10.1016/j. foodcont.2018.01.030

Zhelev, I., Barman, T., Barooah, A.K., Goswami, B.C., Sharma, N., Panja, S., Khare, P. and Karak, T., 2020. Contents of chromium and arsenic in tea (Camellia sinensis L.): extent of transfer into tea infusion and health consequence. Biological Trace Element Research. 196, 318-329. https://doi.org/10.1007/ s12011-019-01889-y

Zhong W-S., Ren, T., Zhao L-J. 2016. Determination of Pb (Lead), $\mathrm{Cd}$ (Cadmium), Cr (Chromium), Cu (Copper), and Ni (Nickel) in Chinese tea with high-resolution continuum source graphite furnace atomic absorption spectrometry. Journal of Food and Drug Analysis. 24: 46-55. https://doi.org/10.1016/j. jfda.2015.04.010 